\title{
COMMENTS
}

\section{FEDERAL VERSUS STATE JURISDICTION OVER STRANGER PICKETING}

A perplexing question in contemporary labor law is whether Congress, in passing the Taft-Hartley Act, ${ }^{1}$ pre-empted the entire field of labor relations in interstate commerce and thereby excluded all state regulation in that field. ${ }^{2}$ This note will be confined to the pre-emption argument in one of the areas of greatest confusion, stranger picketing for organization and recognition. ${ }^{3}$ The subsidiary question of whether pre-emption operates in all areas subject to the NLRB's statutory jurisdiction or only in areas over which it normally assumes jurisdiction will not be discussed here. ${ }^{4}$

Under the Taft-Hartley Act as presently interpreted, union activity may constitute an unfair labor practice under Section 8,5 a protected activity under Section $7,{ }^{6}$ or fall within a middle group of activities which are neither prohibited nor protected by the Act. The Supreme Court's recent decision in Plankinton Packing Co. v. Wisconsin Employment Relations Board apparently holds that state jurisdiction over activities which constitute Section 8 unfair labor practices has been pre-empted. ${ }^{7}$ Other Supreme Court decisions have established

I 61 Stat. 136 (1947), 29 U.S.C.A. \$ 151 et seq. (Supp., 1951).

2 Smith, The Taft-Hartley Act and State Jurisdiction over Labor Relations, 46 Mich. L. Rev. 593 (1948); Cox and Seidman, Federalism and Labor Relations, 64 Harv. L. Rev. 211 (1950); Petro, State Jurisdiction To Control Recognition Picketing, 2 Lab. L.J. 883 (1951); State Jurisdiction To Enjoin Picketing Affecting Interstate Commerce: Extent of Exclusive Jurisdiction of NLRB, 37 Cornell L.Q. 515 (1952).

${ }^{3}$ The two objectives are here deliberately combined as they are, practically speaking, on the picket line. The cases, however, necessitate a distinction. See p. 110 infra. Minority picketing is unlike stranger picketing in that it involves picketing by employees, not outsiders. But where the objective of the picketing is organization of the employees and recognition from the employer, minority picketing presents the essential problem of stranger picketing with the important tactical difference that the employer can discharge the minority but not the stranger pickets. Whether such a discharge would constitute an unfair labor practice depends on whether the picketing is a protected activity under Section 7 of the Taft-Hartley Act. This question is considered in the body of the present discussion in relation to stranger picketing. No decision has been found which clearly differentiates between stranger picketing for organization and recognition and minority picketing for the same purpose. Grounds for such a differentiation are adumbrated in NLRB v. Draper Corp., 145 F. 2d 199 (C.A. 4th, 1944). See Cox, The Right To Engage in Concerted Activities, 26 Ind. L.J. 319, 331-32 (1951).

"See Feldblum, Jurisdictional "Tidelands" in Labor Relations, 38 Va. L. Rev. 187 (1952).

561 Stat. 141 (1947), 29 U.S.C.A. \& 158 (Supp., 1951).

- 61 Stat. 140 (1947), 29 U.S.C.A. $\$ 157$ (Supp., 1951).

7338 U.S. 953 (1950); cf. Amazon Cotton Mill Co. v. Textile Workers Union, 167 F. 2d 183 (C.A. 4th, 1948). For an explanation of the meaning of the cryptic Plankinton decision, see 
that the states may not regulate conduct which constitutes protected activity under Section $7 .^{8}$ The as yet unresolved question is the extent of state jurisdiction over the middle group of activities. ${ }^{9}$ Although the Taft-Hartley Act neither prohibits nor protects such activities, it may be argued that Congress, by enacting a comprehensive regulation of labor relations in interstate commerce, intended to "occupy" that entire field and thereby excluded state regulation even in the middle area. ${ }^{10}$ The argument is particularly germane to stranger picketing since such picketing, as the following discussion will show, has not been clearly prohibited or protected by the Act. ${ }^{11}$

Any discussion of stranger picketing will be further complicated by the fact that some courts have drawn a distinction between picketing for recognition and picketing for organization which has important consequences for the preemption arguments. ${ }^{12}$ Picketing for recognition has been enjoined on the ground that its objective is the unlawful one of forcing the employer to coerce his employees to accept an unwanted union as their bargaining representative. But organizational picketing is said to involve only a demand upon the employees to joint the union and not to be directed at employer coercion of employees. ${ }^{13}$ Since the courts which make this distinction do not hold the organizational picketing to be unlawful coercion of the employees, placards which exhort "Join us!" may be legal while those which read "Recognize us!" invite injunctions. ${ }^{14}$

The distinction between picketing for recognition and picketing for organization is unrealistic. The resultant pressure on and harm to the employer and his

Cox and Seidman, Federalism and Labor Relations, 64 Harv. L. Rev. 211, 220-21 (1950). There is considerable doubt that the doctrine will be applied to violent activity even though such activity is an unfair labor practice under $\S 8(\mathrm{~b})(1)$ (A), 61 Stat. 141 (1947), 29 U.S.C.A. $\S 158(\mathrm{~b})(1)$ (A) (Supp., 1951). See Petro, State Jurisdiction to Regulate Violent Picketing, 3 Lab. L.J. 3 (1952).

8 Hill v. Florida, 325 U.S. 538 (1945); International Union, UAW, AFL v. Wisconsin Employment Relations Board (hereafter called Briggs-Stratton), 336 U.S. 245 (1949); United Automobile Workers, CIO v. O'Brien, 339 U.S. 454 (1950); Amalgamated Ass'n of Street Ry. Employees v. Wisconsin Employment Relations Board (hereafter called Bus Employees), 340 U.S. 383 (1951).

${ }^{9}$ See, e.g., Goodwins v. Hagedorn, 303 N.Y. 300, 101 N.E. 2d 697 (1951), rehearing denied, 303 N.Y. 673,102 N.E. 2 d 833 (1951).

${ }^{10}$ See discussion p. 116 infra.

11 This note will not deal with the substantive state law of stranger and minority picketing. The states differ on the legality of such picketing and the decisions result from an interplay of common-law, statutory and constitutional doctrines. Peaceful Picketing to Force Employees to Join Union or to Compel Employer to Enter into a Contract Which Would in Effect Compel Them to Do So, 11 A.L.R. 2d 1338 (1950).

12 Park \& Tilford Import Corp. v. Local 848, AFL, 165 P. 2d 891, 896 (1946); Peters v. Central Labor Council, 169 P. 2d 870, 875-76 (1946); Wolferman v. Root, 204 S.W. 2d 733, 735 (Mo. App., 1947); Building Service Employees v. Gazzam, 339 U.S. 532, 539-40 (1950); Goodwins v. Hagedorn, 21 CCH Lab. Cas. I 66,893 (N.Y.S. Ct., 1952).

${ }^{13}$ See, e.g., Goodwins v. Hagedorn, 21 CCH Lab. Cas. ๆ 66, 893 (N.Y.S. Ct., 1952).

14 Authorities cited note 12 supra. 
employees is precisely the same whether the picketing is said to be for one purpose or the other. If the legality of stranger picketing be made to turn on the avowed purpose of the picketing, the union need merely change the rhetoric of its placards to legalize its conduct. Nor would a union find it difficult to justify its use of organizational rhetoric even though its ultimate objective were recognition. This is so because a union's status is not finally secure until it becomes a bona fide majority union, since the employer who recognizes a stranger or minority union runs a risk of subjecting himself to an NLRB cease and desist order which will prevent dealings with the union until it obtains an uncoerced majority. ${ }^{15}$ Organization as well as recognition must therefore be a union objective, and any outlawing of stranger picketing ought to proceed on a theory of coercion of the employer and of the employees, regardless of whether the stated purpose of the picketing be recognition or organization.

But the organization-recognition distinction, however unrealistic it may be, has been accepted by some courts, and attention will have to be directed to its consequences throughout the following discussion. Perhaps it ought to be noted, by way of oblique justification of the courts, that the Taft-Hartley Act itself appears to distinguish the two types of picketing. Section $8(b)(4)(C),{ }^{16}$ which prescribes picketing for recognition in the face of an outstanding certification, is limited by its language to recognition activities only. Organizational picketing is covered, if at all, by a separate section, $8(\mathrm{~b})(1)(\mathrm{A}) .{ }^{17}$

I

Under a literal construction of Section 8(b)(1)(A) picketing for organization appears to be an unfair labor practice: "It shall be an unfair labor practice for a labor organization or its agents to restrain or coerce employees in the exercise of the rights guaranteed in Section 7."18 One of the rights so guaranteed is the right to refrain from joining a labor union. The NLRB has, however, not interpreted Section $8(\mathrm{~b})(1)(\mathrm{A})$ as proscribing organizational activity.

The first NLRB decision interpreting Section $8(\mathrm{~b})(1)(\mathrm{A})$, Maritime Union of America, ${ }^{19}$ involved a majority strike for a hiring-hall contract. The Board, relying on the legislative history of the section, concluded that Congress intended to eliminate only physical violence, intimidation, and the use by unions of threats of economic action against specific individuals to compel them to join. Since the strike in the Maritime case involved no violence, was directed against the employer, not against employees, and could not have been an attempt to force any specific individuals to join because all employees were already union members, the Board held that the strike did not violate Section 8(b)(1)(A).

${ }^{15}$ Labor Management Relations Act, 1947, at $\S 8(a)$ (2), 61 Stat. 140 (1947), 29 U.S.C.A. $\$ 8(a)$ (2) (Supp., 1951). See Midwest Piping and Supply Co., 63 N.L.R.B. 1060 (1945).

${ }^{16} 61$ Stat. 141 (1947), 29 U.S.C.A. $\$ 158(b)$ (4)(C) (Supp., 1951).

${ }^{17} 61$ Stat. 141 (1947), 29 U.S.C.A. $\$ 158$ (b)(1)(A) (Supp., 1951).

1861 Stat. 141 (1947), 29 U.S.C.A. $\$ 158($ b)(1)(A) (Supp., 1951).

1978 N.L.R.B. 971 (1948). 
Nonetheless the hiring-hall contract sought by the union would in practice have discriminated against nonmembers and would have forced prospective employees to join the union as a practical prerequisite to employment. Board member Gray accordingly dissented on the ground that this sort of coercion constituted a violation of Section $8(\mathrm{~b})(1)(\mathrm{A}) .{ }^{20}$ But a majority of the Board apparently felt that coercion of prospective employees was too remote to come within the ban of the section. ${ }^{21}$ The majority indicated, however, that the result might be opposite where the coercion was directed at present, not merely prospective, employees, and where its primary purpose was to compel employees to join the union and not, as in the Maritime case, to gain a particular kind of contract.22

In two later cases, where the economic coercion was in fact aimed at forcing specific persons, already employees, to become or remain members of the union, the Board did hold that such coercion violated Section 8(b)(1)(A). In Clara-Val Packing Co. a threat to strike for the purpose of forcing the employer to discharge an employee who would not join the union was held to constitute an independent violation of both Sections $8(\mathrm{~b})(1)(\mathrm{A})$ and $8(\mathrm{~b})(2) \cdot{ }^{23} \mathrm{~A}$ similar result obtained in Pinkerton's National Detective Agency, ${ }^{24}$ which involved a strike for the purpose of forcing the employer to discharge employees who refused to pay their union dues. It is important to note that the Board has held that a violation of $8(\mathrm{~b})(1)(\mathrm{A})$ may not be found as a mere consequence of a violation of another section. ${ }^{25}$ Clara-Val and Pinkerton's therefore stand for the proposition that a union violates Section $8(\mathrm{~b})(1)(A)$ when it seeks to coerce specific employees to join or remain members of the union by a peaceful strike or by a threat to strike. ${ }^{26}$ The differences between such conduct and stranger picketing for or-

${ }^{20}$ Ibid., at 993-94.

${ }^{21}$ Or perhaps they felt that possible coercion (because the objective of the strike was not attained) of prospective employees was too remote. Had the strike been successful and had the hiring hall contract been signed, the union might then have been guilty of violating $\S 8(\mathrm{~b})(1)$ (A). New York State Employers Association, 93 N.L.R.B. 127, 129 (1951).

22 "The touchstone of a strike which is violative of Section $8(\mathrm{~b})(1)(\mathrm{A})$ is normally the means by which it is accomplished, so long as its objective is directly related to the interests of the strikers, and not direted primarily at compelling other employees to forego the rights which Section 7 protects. ... [T] his strike, though violative of Section 8(b)(2), had as its printe objective the protection of the employment interests of NMU members, and not the coercing of nonmembers to join the union." (Emphasis partly added.) 78 N.L.R.B. 971, 986 (1948).

${ }^{23}$ Clara-Val Packing Co., 87 N.L.R.B. 703, 705 (1949). See also Union Starch and Refining Co., 87 N.L.R.B. 779,787 (1949); N.Y. Shipbuilding Corp., 89 N.L.R.B. 1446 (1950); General American Aerocoach Corp., 90 N.I.R.B. 239 (1950).

2490 N.L.R.B. 205 (1950).

${ }^{25}$ Nat'l Maritime Union, 78 N.L.R.B. 976, 985-86 (1948); Carpenters and Joiners, 80 N.L.R.B. 533, 539 (1948).

${ }^{26}$ In an earlier decision the Board had apparently construed the legislative history of Section $8(\mathrm{~b})(1)(A)$ more narrowly than it did in the Maritime case and decided that it was "intended to proscribe only the coercive conduct which sometimes accompanies a strike but not the strike itself." Perry Norwell Co., 80 N.L.R.B. 225, 239 (1948). Such an interpretation, which would have immunized all peaceful picketing from Section $8(b)(1)(A)$, seems clearly inconsistent with the later Clara-Val and Pinkerton's decisions. 
ganization are slight-the weapon in the latter case is picketing, not striking, and the employees against whom the coercion is directed are more numerous, generally all the employees in a plant.

The Board has held, however, in its only decision to date on stranger picketing for organization, United Brotherhood Carpenters and Joiners, ${ }^{27}$ that such picketing does not constitute an unfair labor practice under Section 8(b)(1)(A). The defendant union picketed a store where only nonunion employees worked. The Board found "that the picketing of Watson's by Local $74 \ldots$ was for the purpose of inducing, directly or indirectly, the workers . . . to join the union,",28 but it held that the picketing was merely "persuasive" and not "coercive" and accordingly did not violate Section $8(\mathrm{~b})(1)(\mathrm{A}) .{ }^{29}$ It is not clear whether the Board's theory was that peaceful picketing alone cannot be coercive, or that the picketing in Carpenters and Joiners was not coercive because it was ineffective. ${ }^{30}$

The Board has further complicated the status of stranger picketing by tacitly accepting the organization-recognition distinction in a series of recent decisions in cases involving employer petitions for elections. It was held in Bubach and Parkinson Motors, ${ }^{31}$ for example, that picketing is not inconsistent with a disclaimer of majority status and that elections would not be ordered where there had been such a disclaimer. The Board said, "We regard it [the picketing] only as an attempt by the Union ... to organize the employees of the employer and thereby seek to regain its former status as a majority representative." ${ }^{32}$ Evidently it was not contended that the picketing constituted a violation of Section 8(b)(1)(A), and so it is difficult to estimate precisely the effect of this and like decisions on stranger picketing as an unfair labor practice. ${ }^{33}$

The legislative history of Section $8(\mathrm{~b})(1)(\mathrm{A})$ is inconclusive as to whether Congress intended to make stranger picketing an unfair labor practice. In dis-

${ }^{27} 80$ N.L.R.B. 533 (1948).

${ }^{28} \mathrm{Ibid}$., at 547.

20 "The picketing was a method employed by Local 74 to publicize the fact that Watson did not employ union labor, on the theory that some potential customers would not patronize such an establishment, and with the hope that such activity would induce the ... employees to join the Union; but . . . any such effect on said employees was persuasive and not coercive." Ibid., at 549.

30 "It is assumed ... that at least some of the ... employees, aware that the advertising [picketing] was having an adverse effect on the business of their employer, considered the economic advantage of joining the Union. This is not to say that, because the picketing brought some results in loss of business to the employer, it follows that the employees, in order to protect their jobs, were forced to join the Union, especially where no threats were involved. In the case before us it is noted that it actually had no sucb effect ... as there is no evidence that any of Watson's employees joined the Union. The most that can be said in that respect is that the picketing was intended to demonstrate to the non-union workers that it was to their advantage to become union members. It did not constitute restraint or coercion of those employees in the exercise of rights guaranteed under the Act, nor did it have that effect." Ibid., at 547. Query: Would the result have been the same had the "advertising" been so effective that Watson's was forced to close?

2188 N.L.R.B. 1202 (1950). $\quad$ as Ibid., at 1204.

"28e also, Bur-Bee Co. 90 N.L.R.B. 9 (1950); Smith's Hardware Co., 93 N.L.R.B. 1009 (1951); Hamilton's Ltd., 93 N.L.R.B. 1076 (1951); General Paint Corp., 95 N.L.R.B. No. 68 (1951). Compare, Coca-Cola Bottling Co., 80 N.L.R.B. 1063 (1948). See, for a discussion of the cases, Petro, Recognition of Picketing under the NLRA, 2 Lab. L.J. 803, 804-5 (1951). 
cussing the section, Senators Taft and Ball constantly referred to threats of violence, mass picketing, "goonsters," etc. ${ }^{34}$ It might be inferred from such recurrent references that the section was intended to cover only physical as distinguished from economic coercion. But each Senator referred to at least one clear case of peaceful stranger picketing for organization as an abuse which the section would correct, ${ }^{35}$ and Senator Morse apparently shared this view. ${ }^{36}$ The legislative history thus can be invoked to support either view of the scope of Section 8(b)(1)(A), but since the NLRB has apparently abandoned interpretations which restrict the scope of the section to violent or threatening activity, ${ }^{37}$ there no longer appears to be any rational ground for distinguishing between stranger picketing for organization and the Clara-Val and Pinkerton's situations. To date, however, the Carpenters and Joiners decision has not been overruled. ${ }^{38}$

\section{II}

Assuming that stranger picketing is not a Taft-Hartley unfair labor practice (save, of course, that which violates Section $8(b)(4)(C)$ ), and that state jurisdiction over it is not, therefore, pre-empted by the Plankinton doctrine, the next possibility is that stranger picketing is a protected activity under Section 7 of the Taft-Hartley Act. A holding to this effect would preclude state jurisdiction over such picketing on grounds of conflict with federal law..$^{39}$

Under judicial and Board interpretation of Section 7 there are several classes of labor activity which, though in fact concerted, have been held unprotected by the section. ${ }^{40}$ These include concerted activities in violation of some federal or state statute of general applicability (not restricted to labor-management relations), ${ }^{41}$ and concerted activities in breach of contract. ${ }^{42}$ Also included is a

${ }^{34}$ See, e.g., 93 Cong. Rec. 4017, 4021 (1947).

${ }^{35}$ Senator Taft: "We had a case last year where a union went to a plant in California and said, 'We want to organize your employees. Call them in and tell them to join our union.' The employers said, 'We have not any control over our employees. We cannot tell them, under the NLRA.' They said, 'If you don't we will picket your plant'; and they did picket it, and closed it down for a couple of months. Coercion is not merely against union members; it may be against all employees." Tbid., at 4024 . And see Senator Ball's relation of a similar incident, ibid., at 4017 .
${ }^{36}$ Ibid., at 4430.
${ }^{37}$ See note 26 supra.

${ }^{88}$ Where employees had voted in a National Board election against joining the picketing union, one federal court held stranger picketing for organization to be a violation of $\S 8$ (b)(1)(A). Pocahontas Terminal Corp. v. Portland Bldg. Constr. Trade Council, 93 F. Supp. 217 (S.D. Me., 1950).

${ }^{39}$ See note 8 supra.

${ }^{40}$ For a general discussion, see Cox, The Right to Engage in Concerted Activities, 26 Ind. L.J. 319 (1951).

il Southern S.S. Co. v. NLRB, 316 U.S. 31 (1940). It has been suggested that state statutes which do no more than fix the outside limits of the collective bargain also belong in the category. Cox, The Right to Engage in Concerted Activities, 26 Ind. L.J. 319, 341-43 (1951).

42 NLRB v. Sands Mfg. Co., 306 U.S. 332 (1939). 
class of cases involving the use of tactics other than an ordinary strike or picketing, for example, the sit-down strike, ${ }^{43}$ the "quickie" strike, 44 the slowdown," and various kinds of insubordination. ${ }^{46}$ Stranger picketing, however, if peaceful, does not violate any non-labor law and need not violate any contract. Nor does it appear to fall within the class of the unusual tactics cases, since it utilizes only the traditional device of peaceful picketing.

In another group of cases, however, the protection of Section 7 was withheld from labor activity which could not attain its objective unless the employer violated a federal law or state statute of general applicability, ${ }^{47}$ or committed an unfair labor practice. ${ }^{48}$ On this latter ground, concerted activity for recognition while certification proceedings are pending before the NLRB has been denied protection because the employer's compliance with the union's demand would constitute interference with his employees' choice of representatives and thus amount to an unfair labor practice under Section 8(a)(2). ${ }^{49}$ Whether the same result would be reached absent the certification proceedings is conjectural,

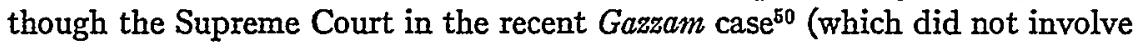
interstate commerce) refused to strike down a state court's use of the interference with employees rationale where there was not even a rival union on the scene. Little reason appears for refusing to apply this rationale to all cases in which the union seeking recognition is not a majority union. ${ }^{51}$ But the Gazzam decision carefully noted that the Court was confronted with recognition and not organizational picketing and thereby emphasized that the cases which declare recognition picketing unprotected by Section 7 are not necessarily precedents for organizational picketing cases. ${ }^{52}$

There is, however, a last possibility for holding organizational stranger picketing unprotected by Section 7. The NLRB has said that "where the objectives sought were inconsistent with the terms or the clearly enunciated policy

${ }^{13}$ NLRB v. Fansteel Metallurgical Corp., 306 U.S. 240 (1939).

4 Briggs-Stratton, 336 U.S. 245 (1949).

${ }^{45}$ Elk Lumber Co., 91 N.L.R.B. 333 (1950).

${ }^{26}$ See, e.g., NLRB v. Mt. Clemens Pottery Co., 147 F. 2d 262 (C.A. 6th, 1945); NLRB v. Montgomery Ward \& Co., 157 F. 2d 486 (C.A. 8th, 1946).

${ }^{47}$ See, e.g., American News Co., 55 N.L.R.B. 1302 (1944).

18 Thompson Products Inc., 70 N.L.R.B. 13 (1946), vacated 72 N.I.R.B. 886 (1947).

49 Hoover Co. v. NLRB, 191 F. 2 d 380 (C.A. 6th, 1951); Goodwins v. Hagedorn, 303 N.Y. 300,101 N.E. $2 d 697$ (1951).

so Building Service Employees v. Gazzam, 339 U.S. 532 (1950).

51 Where a union is certified, or where there is no certification but one union clearly has majority status, the employer's duty to bargain with the majority union is said to carry with it the negative duty to recognize and bargain with no other. Medo Photo Supply Corp. v. NLRB, 321 U.S. 678 (1944); NLRB v. Jones \& Laughlin Steel Corp., 301 U.S. 1 (1937). Picketing for recognition by a minority or stranger union could therefore be declared unprotected because its objective was to coerce the employer to violate this duty. But where there is no majority union, this explanation will not do, and the $\S 8(\mathrm{a})(2)$ rationale must be used.

32 Building Service Employees v. Gazzam, 339 U.S. 532, 539-40 (1950). 
of this Act [Taft-Hartley]," the activity might be excepted from the coverage of Section $7 .{ }^{53}$ Applying this criterion, which probably explains the breach of contract cases, ${ }^{54}$ it could be argued that one of the fundamental objectives of the Taft-Hartley Act is to encourage collective bargaining between employers and unions representing free, uncoerced majorities of the employees; that election procedure for selecting employee representatives has been provided; that one of the objectives of stranger picketing is to bypass this procedure and ccerce workers into a choice of representatives; and that consequently such picketing violates a fundamental policy of the Act and should not be designated a protected activity. ${ }^{55}$ But no case has been found which clearly applies this reasoning to organizational picketing.

\section{III}

Even if stranger picketing for organization should be declared unprótected as well as not prohibited by the Taft-Hartley Act, doubt would still exist as to whether the states could constitutionally assume jurisdiction over such picketing. The three possibilities are that the states have jurisdiction over none, all or some of the activities falling within this middle group.

Support for the proposition that the states have been ousted of jurisdiction even over activities unprotected and unprohibited by the Taft-Hartley Act may be found in the Supreme Court's most recent statement on pre-empticn under the Taft-Hartley Act, Bus Employees v. Wisconsin Board..$^{56}$ The Court declared that the Taft-Hartley Act pre-empted the field which it covered, ${ }^{57}$ and stated that its coverage was the field of labor relations to the full extent of Congress' power to regulate in that area. ${ }^{58}$ As if to nail down the obvious inference, the Court clearly implied that the states had jurisdiction to regulate labor relations in interstate commerce only where jurisdiciion was ceded to them by the federal government. ${ }^{59}$ Since it can hardly be contended that Congress does not have the power to regulate stranger picketing, it would follow that the states could not regulate such picketing whether or not Congress had seen fit to place it within one of the sections of the Taft-Hartley Act.60

The narrow holding of the Bus Employees case, however, was that a strike for

${ }^{53}$ Hoover Co., 90 N.L.R.B. 1614, 1621 (1950).

${ }^{54}$ See Cox, The Right to Engage in Concerted Activities, 26 Ind. L.J. 319, 328-30 (1951).

${ }^{5 s}$ Petro, State Jurisdiction to Control Recognition Picketing, 2 Lab. L.J. 883 (1951); Lauritzen, The Organizational Picket Line, 3 Stanford L. Rev. 413 (1951). But cf. Cox, The Right to Engage in Concerted Activities, 26 Ind. L.J. 319, 327-28 (1951).

$$
\begin{array}{ll}
{ }^{86} 340 \text { U.S. } 383 \text { (1951). } & \quad 58 \text { Tbid., at } 391 . \\
{ }^{57} \text { Tbid., at 397-98. } & { }^{39} \text { Tbid., at 397-98. }
\end{array}
$$

${ }^{60} \mathrm{~A}$ rather involved argument has been made urging that the particular field of minority and stranger picketing has been pre-empted. See Feldblum, Some Aspects of Minority Union Picketing in New York, 20 Fordham L. Rev. 176, 194-96 (1951). But cf. Cox and Seidman, Federalism and Labor Relations, 64 Harv. I. Rev. 211, 225-27 (1950). 
higher wages by utility employees was a protected activity under Section 7 , and that state regulation of such a strike conflicted with federal law. It may be argued, therefore, that the pre-emption dictum does not apply to middle group activities because the Court was not confronted with a case involving such activities and there is no explicit indication that it intended its language to apply to them. On the other hand, the fact that the Court did not rest its holding on the narrower ground that the state regulation involved was in conflict with federal law may be said to underscore the significance of its broad pre-emption language.

The view that the states may regulate any activity which is neither protected by Section 7 nor unfair under Section 8 may be supported by language in an earlier Supreme Court case, Briggs-Stratton. ${ }^{61}$ The employees had engaged in a series of unannounced work stoppages-the "quickie" strike. The Court found that this activity was not protected by Section 7, and in upholding the right of the state to enjoin such practices Justice Jackson stated:

It seems to us clear ... that the state may police these strike activities ... because "Congress has not made such employee and union conduct as is involved in this case subject to regulation by the Federal Board." There is no existing or possible conflict or overlapping between the authority of the Federal and State Boards, because the Federal Board has no authority either to investigate, approve or forbid the union conduct in question. This conduct is governable by the state or it is entirely ungoverned."2

This language may be interpreted as affirming the existence of state jurisdiction over all activities falling within the middle group. In context, however, it appears that Justice Jackson may have been referring not to all middle group activities but only to "coercive tactics."

However, as to coercive tactics in labor controversies, we have said ... that "Congress designedly left open an area for state control" and that "the intention of Congress to exclude States from exercising their police power must be clearly manifested."

Another statement in the opinion, though inaccurate, indicates that the phrase "coercive tactics" was used to refer to the use of illegal means in a labor dispute, as distinguished from the pursuit of an illegal objective by lawful means. ${ }^{64}$ Arguably, then, action neither prohibited nor protected by the Taft-Hartley Act would be subject to state regulation only when illegal means were employed, for in such cases "the intention of Congress to exclude the States from exercising their police power must be clearly manifested." The implication is that where

61 Briggs-Stratton, 336 U.S. 245 (1949). For various reasons, a dictum in Algoma Plywood \& Veneer Co. v. Wisconsin Employment Relations Board, 336 U.S. 301, 305 (1949), which also supports this proposition, would probably carry little weight in pre-emption arguments today. See Cox and Seidman, Federalism and Labor Relations, 64 Harv. L. Rev. 211, 223-24 (1950).

62 Briggs-Stratton, 336 U.S. 245, 254 (1949).

${ }^{63}$ Ibid., at 253.

61 "While the Federal Board is empowered to forbid a strike, when and because its purpose is one that the Federal Act made illegal, it has been given no power to forbid one because its method is illegal." Ibid. Cf. $\$ 8(\mathrm{~b})(1)(\mathrm{A})$ of Taft-Hartley. 
only the objective of the union and not the means employed was prescribed by state policy, it would be unnecessary to show a specific intent to exclude the states from jurisdiction; exclusion would follow from Congress' "intent" (recognized in the Bus Employees case) to pre-empt the field. Presumably a due process test would prevent the states from breaking down the means-objective distinction and expanding their own jurisdiction by simply designating as illegal means all activities which they desired to regulate.

It is questionable, however, whether even a flexible due process test could prevent the breakdown of a distinction which seems little more than a matter of definition. For example, the secondary boycott, an illegal means at common law, is defined in terms of objectives in Taft-Hartley. ${ }^{65} \mathrm{As}$ regards stranger picketing, it could as well be argued (a) that peaceful picketing is a traditionally acceptable means and that its use has been held protected where the objective is, e.g., higher wages, and that therefore, if peaceful picketing is condemned when its objective is organization, the objective sought and not the means employed must have dictated the changed result; or (b) that an attempt to organize workers by, e.g., writing letters, would plainly be legal and that therefore an attempt to attain the same objective by another means, e.g., peaceful picketing, must be condemned, if it is condemned, only because of the means employed.

It would be undesirable for such verbal distinctions to be controlling and it would be unfortunate if Briggs-Stratton were read so as to require this result. If Briggs-Stratton were so read and the argument that stranger picketing involved only the use of the legal means of peaceful picketing were used to preclude state regulation of stranger picketing (as would seem likely in view of the Gazzam decision), it would lead to the anomalous result that activity which had been thought so inconsistent with the policy of free choice as to merit exclusion from the protection of Section 7 would not only be immune from employer reprisal (the employer could hardly discharge pickets who were not his employees), but would be free from state regulation as well. Such a result could be justified as a matter of policy only if a very great premium were set upon uniformity in regulating labor-management relations.

Arguments for uniformity are, of course, easy to make. It has been persuasively contended, for example, that the federal government should retain full responsibility in areas where it has enacted comprehensive regulations even at the cost of tolerating a few overlooked abuses, and that the cost to the community "of tolerating the abuses pending Congressional action would seem to be far less than the expense of litigation and patch-work policies." ${ }^{\prime 66}$ Where, however, an activity challenges the fundamental policy of federal labor legislation, as stranger picketing does, it is highly undesirable that the abuse be tolerated even temporarily. Although it would be anomalous if a matter central to the activities of

${ }^{65}$ Labor Management Relations Act, 1947, at $\S 8(\mathrm{~b})(4)$ (A), 61 Stat. 141 (1947), 29 U.S.C.A. $\S 158$ (b)(4)(A) (Supp., 1951).

${ }^{65}$ Cox and Seidman, Federalism and Labor Relations, 64 Harv. L. Rev. 211, 230 (1950). 
unions and the ultimate policy of the Taft-Hartley Act were left to the vagaries of over forty-eight jurisdictions, ${ }^{67}$ it would be at least equally anomalous if no agency had authority to regulate activity which violated the clearly enunciated policy of the Act. ${ }^{68}$

Consistency with the underlying policy of the Act and desirable uniformity of administration could both be attained if Section $8(\mathrm{~b})(1)(\mathrm{A})$ were used to regulate stranger picketing. It has already been urged that the NLRB's interpretation of that section is not so settled as to preclude its use for such a purpose. If, however, the NLRB does not change what appears to be its present interpretation of Section 8(b)(1)(A), amendment of the Taft-Hartley Act would be the proper way to achieve uniform policing of stranger picketing. Meanwhile, though the cases may cast substantial theoretical doubt on the states' jurisdiction to regulate stranger picketing for organization and recognition, pre-emption arguments will be unlikely to commend themselves to state courts impressed with the coercive nature of such picketing. ${ }^{69}$

\section{THE ASSIGNMENT OF CLAIMS ACT OF 1940}

\section{ASSIGNEE v. SURETY}

The Assignment of Claims Act of $1940^{1}$ was passed for the purpose of giving protection to banks, trust companies and other lending institutions engaged in the financing of defense contracts. Formerly, assignment of claims against the government had been barred. ${ }^{2}$ The Act of 1940 enabled lenders to accept as security assignments by contractors of payments due and to become due under such contracts. Banking interests attribute the success of the World War II V-loan program to the liberalizing effect of the 1940 Act. $^{3}$

${ }^{67}$ Tbid., at 228-30.

${ }^{68}$ Petro, State Jurisdiction to Control Recognition Picketing, 2 Lab. L.J. 883 (1951).

69 See, e.g., State v. Dobson, 245 P. 2d 903, 923 (1952).

154 Stat. 1029 (1940), as amended, 31 U.S.C.A. $\$ 203$ (Supp., 1951).

29 Stat. 41 (1846), 31 U.S.C.A. $\$ 203$ (1927); 12 Stat. 596 (1862), 41 U.S.C.A. $\$ 15$ (1952).

${ }^{3}$ See Kupfer, The Federal Assignment of Claims Act Comes of Age, 125 N.Y.B.J., Nos. 107, 108 and 109 (1951). In 1951, the Act of 1940 was reconsidered by Congress in the light of the new financing made necessary by the Korean situation. Under the impact of two "adverse" opinions by the Comptroller General, the Act of 1940 was amended, 31 U.S.C.A. $\$ 203$ (Supp., 1951). The Comptroller had advised that the government could recapture payments made to an assignee-bank if the contractor failed to pay withholding taxes or make social security contributions, or in case of price revision under the contract. Although in no single reported case had the government made such recapture from a financing institution, and in spite of the questionable validity of the Comptroller's opinion (cf. United States v. Hadden, 192 F. 2d 327 [C.A. 6th, 1951]), it was feared that the effect of these rulings might be to deter lenders from participating in the current mobilization program. Accordingly, the Act of 1940 was amended so as to overcome the Comptroller's decisions. The Amendment of 1951 provides, in effect, that the government may not recover any part of payments made to an assigneelender after July 1,1950 , for debts of the contractor arising from or independently of contracts awarded by certain government agencies to be designated by the President in time of emergency. See Cable, 1951 Assignment of Claims Amendment; Boon to Government Contract Financing, 68 Banking L.J. 437 (1951). 